\title{
Il disegno per l'infanzia al tempo della pandemia: l'esperienza del C.I. di Disegno, Arte e Musica di UniBg
}

\author{
Alessio Cardaci
}

Abstract

L'insegnamento del Disegno all'interno dei corsi di laurea in Scienze della Formazione Primaria sollecita nuove riflessioni del nostro settore al fine di una rimodulazione della didattica, non più rivolta alla formazione di ingegneri e architetti, ma di educatori. Figure professionali che dovranno impiegare lo strumento grafico non per la comprensione e la valorizzazione dell'architettura e del paesaggio, ma come mezzo fondamentale per la comunicazione dello spazio interiore del bambino. Una concezione allargata della disciplina, priva di un legame diretto con la rappresentazione del patrimonio architettonico e naturale, incardinata su una stretta relazione con le arti visive e le dottrine di storia dell'arte e scienze sociali. La crisi pandemica ci ha chiamato a nuove sfide costringendoci all'uso intensivo della didattica digitale 'in remoto'; il saggio presenta delle riflessioni nate dall'esperienza maturata all'interno del corso di Disegno, Arte e Musica attivo presso l'Università degli Studi di Bergamo, evidenziando come il blended learning possa offrire, se impiegato nel modo adeguato, nuove opportunità per superare i limiti dell'educazione tradizionale in sola presenza.

\section{Parole chiave}

Cooperative Learning, arte e musica, scuola primaria, pedagogia, psicologia, Bergamo.

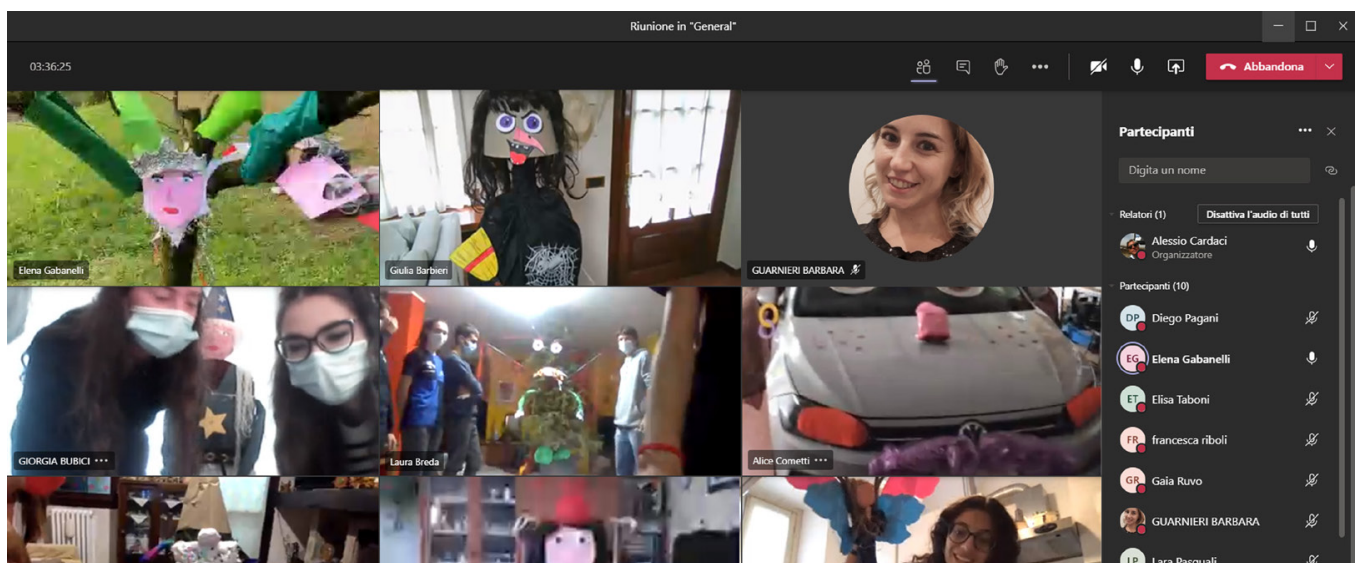




\section{Introduzione}

La crisi pandemica da Coronavirus (Covid 19) ha accelerato una serie di processi che erano già in atto nella nostra società; il mondo dell'università è stato costretto a forti cambiamenti nel settore della didattica ma, soprattutto, ha dovuto attuare profonde modifiche nella modalità di erogazione dei suoi insegnamenti. Gli atenei hanno dovuto intraprendere la strada dell'interazione digitale, combinando le lezioni in presenza con quelle a distanza. Una rivoluzione innescata da cause repentine e inattese che ha obbligato a una trasformazione, concretizzatasi in tempi molto brevi e, forse, possibile solo perché fondata su delle mature riflessioni che hanno animato il dibattito pedagogico degli anni passati. Uno sconvolgimento ancora in essere che, a oggi, non sappiamo quando avrà fine; uno stravolgimento che renderà impossibile un ritorno a uno statu quo prius e, verosimilmente, ci condurrà a una nuova forma di educazione.

II blended learning, termine oggi in auge per indicare una forma di apprendimento ibrido (anche in remoto) attraverso gli strumenti del digitale, ha consentito nel corso del lockdown (e lo permette tuttora durante le chiusure obbligate, quando necessarie a contrastare l'aumento dei contagi), di non interrompere il percorso di apprendimento e la relazione dialettica tra docente e discente, nonché di "mantenere viva la comunità di classe, di scuola, il senso di appartenenza e combattere il rischio di isolamento e di demotivazione" [Bruschi 2020, p. 2]. La grande sfida odierna è la costruzione di nuovi ambienti di apprendimento, nella piena consapevolezza che l'insegnamento "deve prevedere la costruzione ragionata e guidata del sapere attraverso un'interazione tra docenti e alunni: qualsiasi sia il mezzo attraverso cui la didattica si esercita, non cambiano il fine e i principi" [Op. Cit.inserire nome dell'autore, anno, p. 3]. È necessario, quindi, creare nuovi spazi, intesi non solo come luoghi fisici, ma ambienti cognitivi finalizzati a stimolare l'allievo con esperienze significative sul piano emotivo e affettivo, sociale e dei rapporti interpersonali, del sapere e della cultura [Castoldi 2020].

II saggio, attraverso l'esperienza del C.I di Disegno, Arte e Musica attivo presso l'Università degli Studi di Bergamo svoltosi durante la pandemia, propone delle riflessioni di metodo legate all'insegnamento delle discipline della rappresentazione nei percorsi di Scienza della Formazione Primaria, al fine di sfruttare l'esperienza che un evento così negativo ha comunque prodotto.

Fig. I. Gli studenti e le studentesse durante le loro attività: i ragazzi, pur lavorando nelle proprie abitazioni, quando in

coppia o in piccoli gruppi, coppia o in piccoli gruppi, halicato sanitarie al fine del contenimento del contagio.
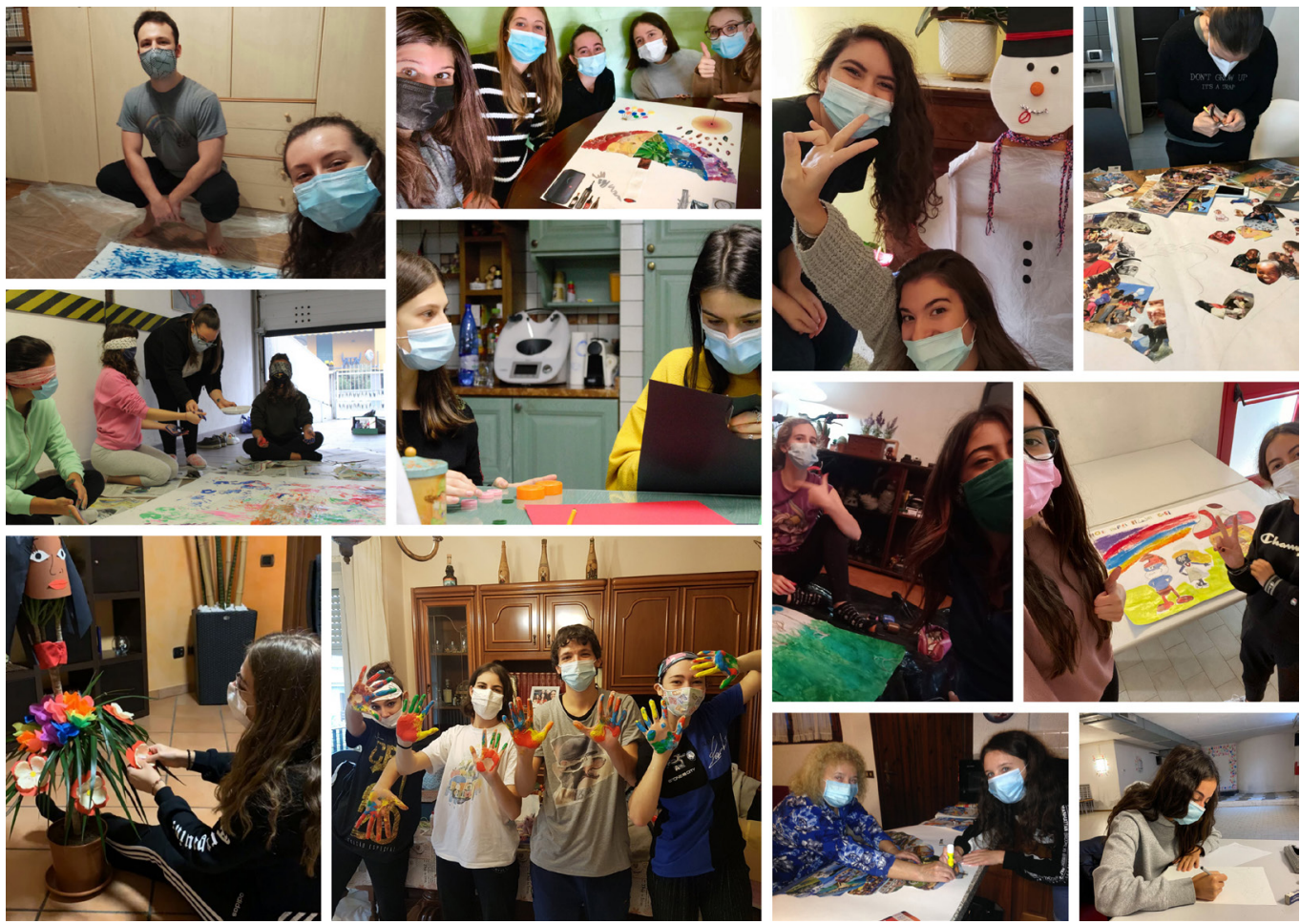


\section{Ambienti di apprendimento e didattica digitale 'in remoto'}

Il sapere (inteso come il rapporto biunivoco e inscindibile tra conoscenza e competenza), e il modo in cui esso si costruisce nell'allievo, è influenzato da una moltitudine di fattori che intercedono nel processo formativo: gli insegnanti e gli allievi, il contesto culturale e sociale, gli strumenti tecnici e metodologici. Essere competenti, infatti, vuol dire padroneggiare la conoscenza ed essere in grado di sfruttare il proprio bagaglio scientifico-culturale per adattarsi a circostanze diverse; è necessario che la trasmissione dei contenuti avvenga all'interno di un rapporto di stretta complicità tra docente e discente per permettere lo stimolo della competenza, donando all'allievo una consapevolezza trasversale e interdisciplinare da impiegare in campi eterogenei e inesplorati [Aiello 2019].

L'ambiente di apprendimento è alla base di questo processo. Esso è un insieme di attività strutturate per la costruzione e il passaggio della sapienza, nonché per stimolare l'interazione tra scolari sulla base di interessi e scopi comuni [Elleran 2020]. La tematica, molto dibattuta nell'ambito delle Scienze dell'Educazione, marca uno spartiacque nella didattica tradizionale attraverso una nuova concezione dell'istruzione fondata non 'sul cosa insegnare' ma 'sul come insegnare'; una nuova visione che incentra la formazione sui bisogni del soggetto che apprende e sui processi in cui questo avviene.

In questo ambito la didattica digitale, anche 'in remoto', è un nuovo e potente strumento al servizio del docente, anche se non privo di criticità; essa deve essere considerata uno strumento integrativo al metodo tradizionale in presenza ma non potrà mai esserne sostitutiva. Infatti, la fruizione individuale delle lezioni dalla propria dimora, pur consentendo la trasmissione di scienza e cultura, desta legittime perplessità sui rischi legati alla dimensione sociale e dei rapporti interpersonali dei fruitori (affermazione che, nell'era dei social network, è abbastanza singolare). Uno studio prettamente autonomo ed esterno alle aule universitarie, pur se apparentemente non sembra intaccare la relazione tra il docente e lo studente (anzi la fortifica per la forma diretta e di immediato utilizzo proprio della comunicazione digitale), certamente altera la percezione dell'accademia.

La didattica digitale a distanza, secondo molti autori, trova il suo fondamento nella concezione educativa teorizzata da Jean-Jacques Rousseau ed espressa nell'opera Émile ou dell'Éducation, pubblicata in Francia nella seconda metà del'700. Un pensiero che è stato rivalutato alla luce della condizione attuale perché, soprattutto nelle considerazioni del ruolo dell'educatore, ben si adatta all'insegnamento 'in remoto' [Nardi 2020]. La formazione dello

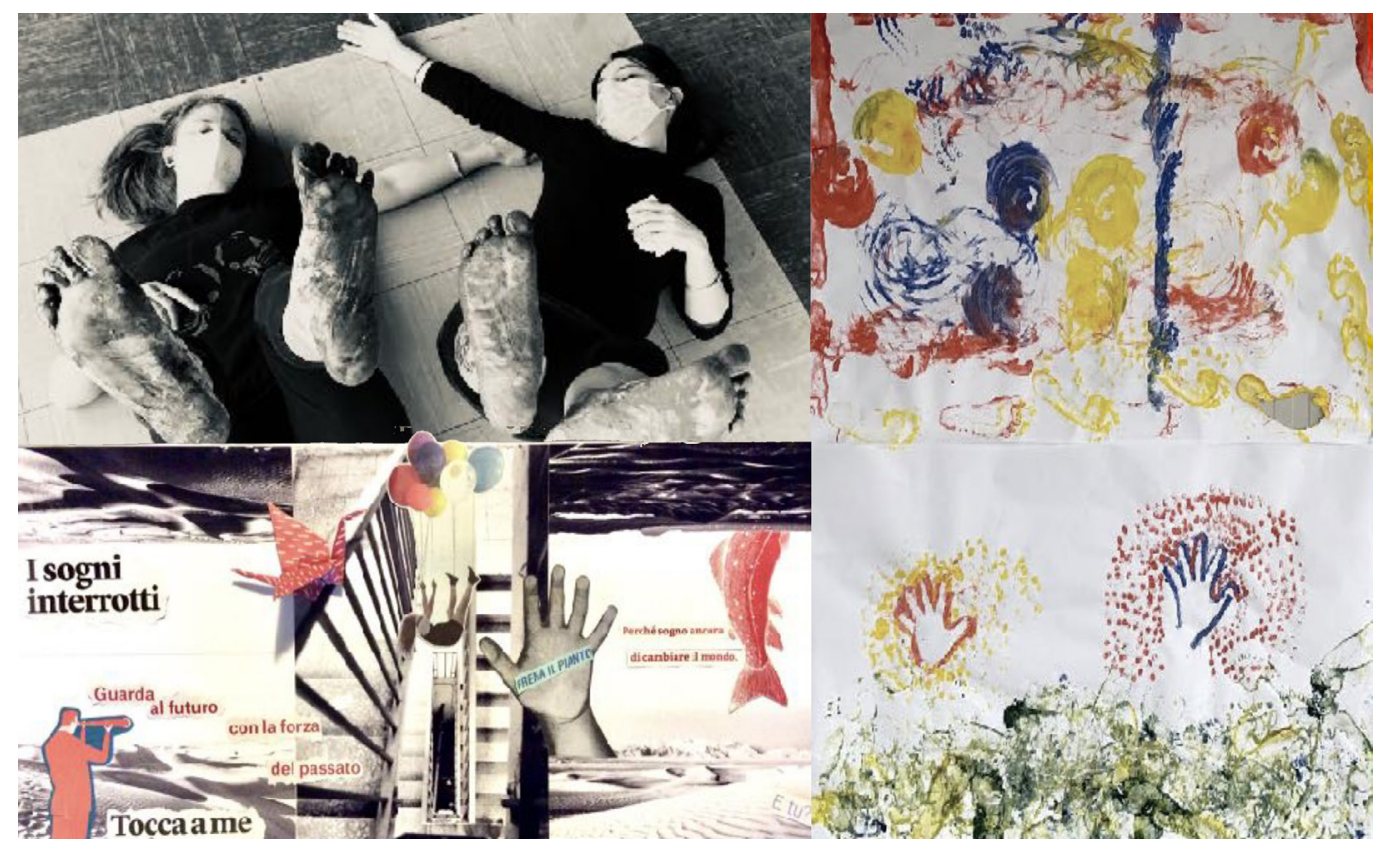


Fig. 3. I gruppi che si sono costituiti all'interno delle famiglie: gli studenti, al fine di realizzare proprie opere hanno coinvolto i propri familiari i propri bimbi).
Fig. 4. I laboratori seguiti nelle scuole dagli student impegnati in attività di supplenza che hanno seguito le lezioni insiemi ai bambini delle scuole primarie coinvolgendoli nelle attività della lezione.
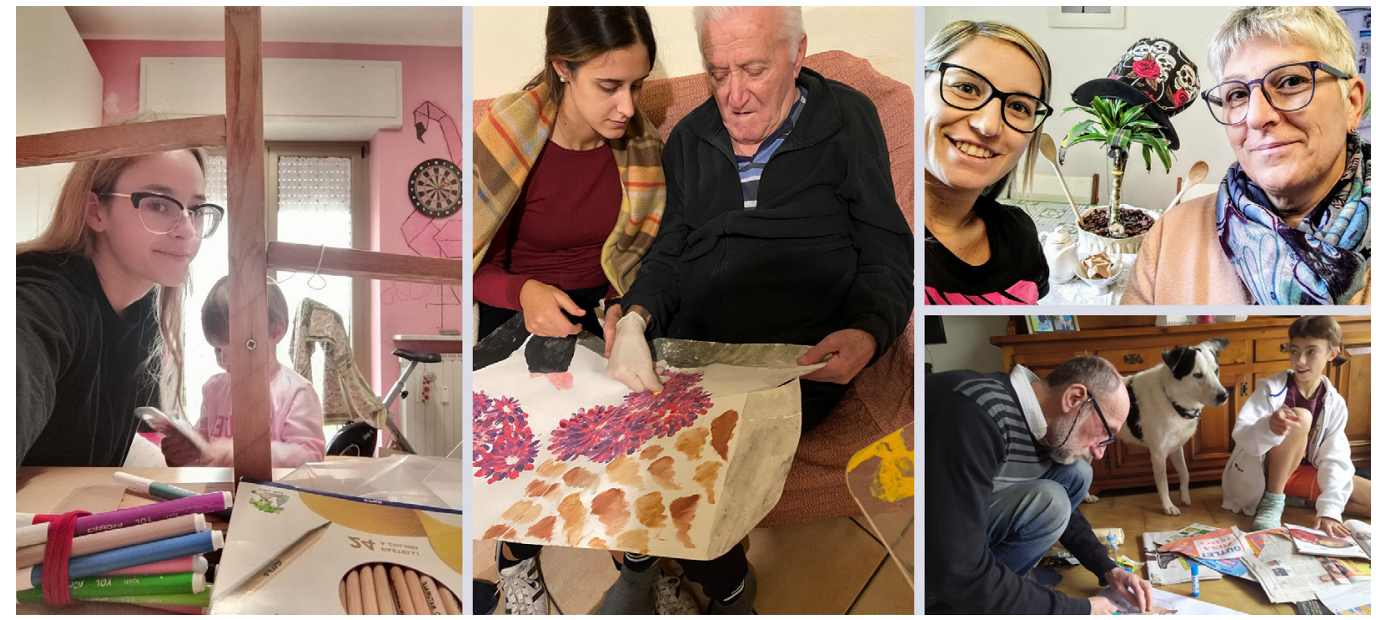

studente, secondo Rousseau, deve avvenire attraverso due forme successive: "l'educazione negativa e l'educazione indiretta".

L'"educazione negativa" è attuata senza alcun intervento del docente il cui ruolo è seguire la formazione dell'allievo senza imporre nulla, perché "unica maestra" deve essere l'esperienza. II precettore deve realizzare un luogo di apprendimento che permetta agli studenti di sperimentare conservando la dimensione spontanea e originale dello spirito dell'allievo; quindi "non già nell'insegnare la virtù e la verità, ma nel preservare il cuore dal vizio e lo spirito dall'errore" [Rousseau 1762-1965, p. 90].

L'"educazione indiretta" si fonda sulla consapevolezza che l'apprendimento non è un fatto puramente intellettuale, ma il risultato del concreto esercizio unito alla riflessione personale; il docente deve guidare il suo allievo senza impartire precetti. La comprensione deve nascere dalla sperimentazione, dal fare delle cose legate all'interesse e stimolate dalla curiosità. L'educatore non deve ricercare i metodi migliori per insegnare ma deve suscitare il desiderio di imparare. II coinvolgimento immediato è, dunque, alla base dell'apprendimento;
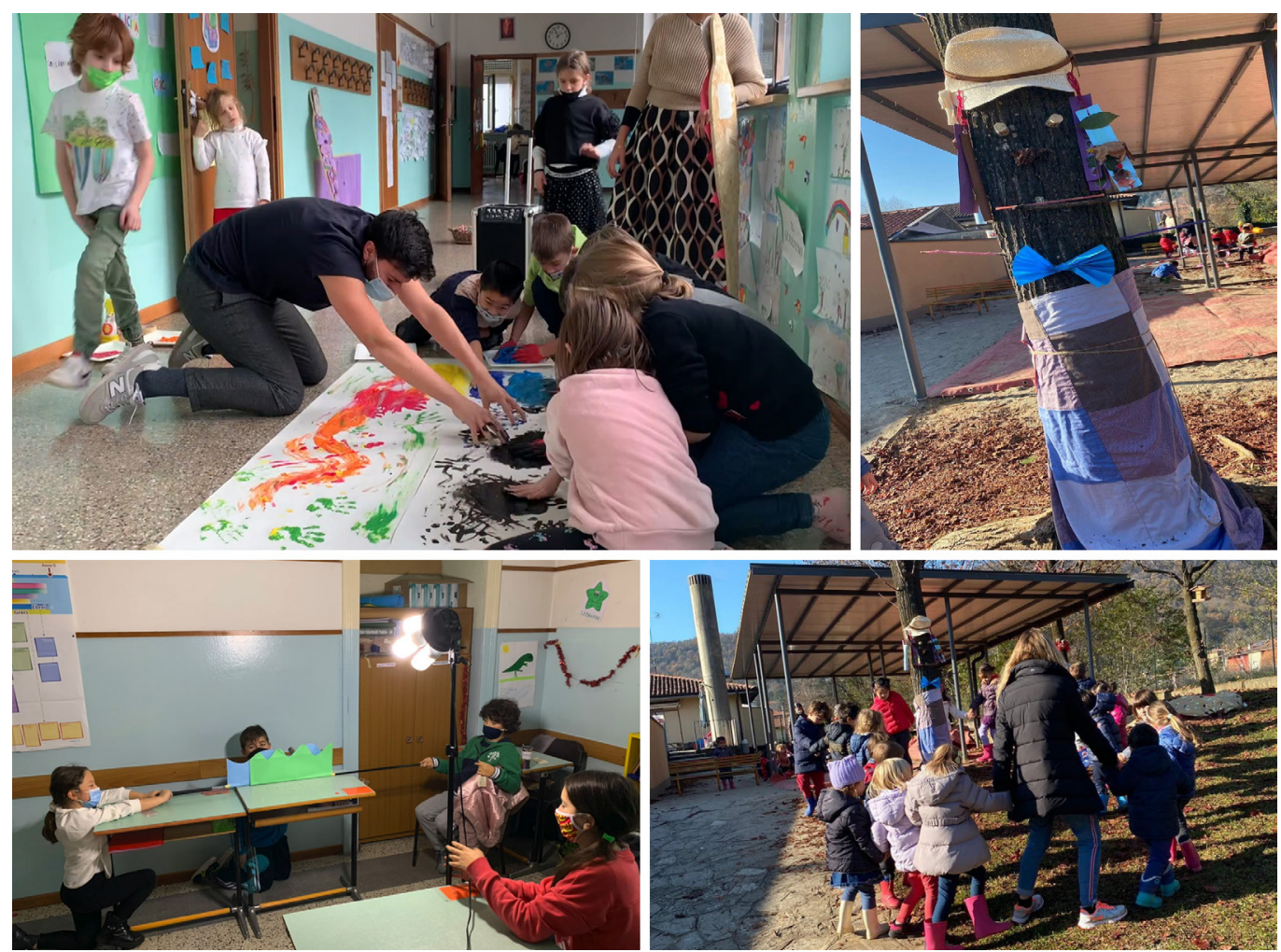
Fig. 5. L'atelier Animare l'inanimato: piante, termosifoni, stufe e sedie si trasformano in figure che ricordano personagg fiabeschi. per essere efficace e presente, attuale e concretò, nonché avere alla base l'utilità. II maestro deve dare l'impressione all'allievo che "faccia tutto senza fare nulla", facendo sì che l'allievo abbia la percezione che le sue esperienze siano casuali, mentre al contrario sono pianificate dall'educatore [Mulè 2019].
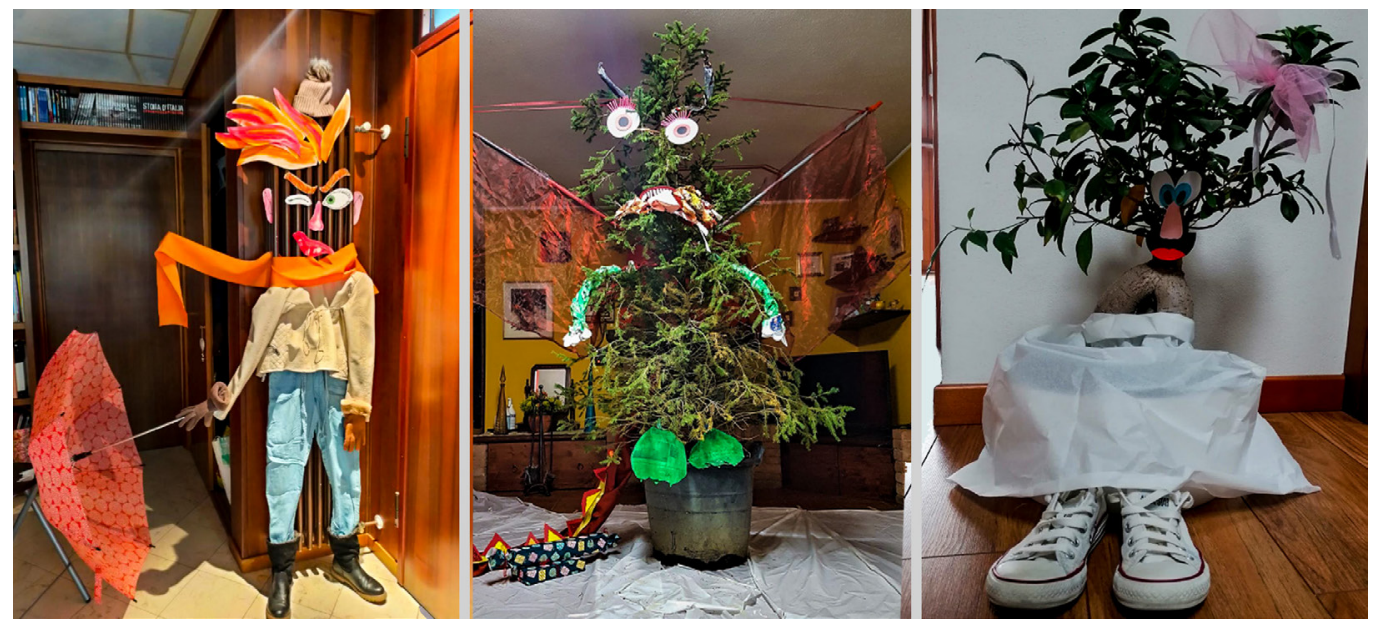

\section{'esperienza del C.I di Disegno, Arte e Musica di Unibg}

II C.I di Disegno, Arte e Musica attivo presso l'Università degli Studi di Bergamo è un insegnamento nato dall'integrazione di competenze tra i settori della pedagogia, della psicologia e della scienza della rappresentazione. Esso si pone come obbiettivo primario l'avvicinamento degli allievi alla percezione e alla comunicazione visiva, di educarli alla lettura delle immagini, di stimolarli all'utilizzo della tecnica grafica quale mezzo espressivo di comunicazione emotiva; una visione del Disegno che intende attribuire al sostantivo il significato "DI sé il SEGNO", relazionando le attività all'individuo che utilizza forme e colori per esprimere il proprio mondo interiore. L'apprendimento è quindi fondato sull'interesse e sul piacere degli studenti di conoscere e arricchire sé stessi e la propria anima. Non è dunque importante dire a un allievo come disegnare ma farlo innamorare del disegno all'interno di un percorso di autoapprendimento che lo stimolerà a crescere e a migliorare [Cardaci 2020].

La pandemia e l'impossibilità di svolgere le normali attività nelle sedi universitarie ha obbligato a una diversa forma di coinvolgimento dei ragazzi. L'obbiettivo prioritario, anche attraverso il digitale, è stato il far rivivere lo 'spirito del corso' come se si svolgesse in presenza, passaggio non semplice per un insegnamento fondato sull'attività laboratoriale quale elemento legante delle varie discipline, tra cui l'azione psicomotoria.

Le piattaforme per la didattica a distanza, a tal scopo, sono state impiegate non come semplice strumento di comunicazione ma come artificio informatico in grado di estendere l'aula oltre i confini fisici dell'ateneo, in modo capillare e diffuso nel territorio (fig. di copertina). Smartphone e tablet si sono tramutati in telecamere per connettere luoghi e realtà distanti tra loro, nonché condividere esperienze ed eventi, gioie e passioni; mezzi di unione sfruttati trasversalmente alle loro originarie funzioni per consentire agli allievi di svolgere 'in sicurezza' gli atelier, senza aver l'impressione di essere isolati o distanti tra loro (fig. I). Un occhio elettronico in grado di osservare e trasmettere le iniziative portate avanti dai singoli gruppi e, nel contempo, uno schermo di visualizzazione sul mondo per essere sempre in stretto e diretto contatto gli uni con gli altri.

A tal fine è stato importante ridurre la funzione accentratrice del docente, spesso totalizzante in una didattica 'in remoto' dove il professore invade il monitor e gestisce i tempi di parola con il controllo dei microfoni [Milito, Tataranni 2019]. Lo svolgimento della lezione, infatti, ha previsto la 'visione' dell'insegnate solamente nella fase iniziale e conclusiva, mantenendo la camera spenta (o in modalità flatting, ridotta a piccola icona in alto) durante il resto del tempo. È stata quindi depotenziata la presenza 'visiva' del professore e la sua funzione 
Fig. 6. L' atelier Disegnare bendati, con mani e piedi: il disegno astratto realizzato senza il senso della vista, vedere il colore con il tatto ed impiegando le mani e i piedi come pennelli per realizzare le proprie opere.
Fig. 7. L' atelier Photo-Collage: il riuso di immagini per la costruzione di una nuova figurazione.
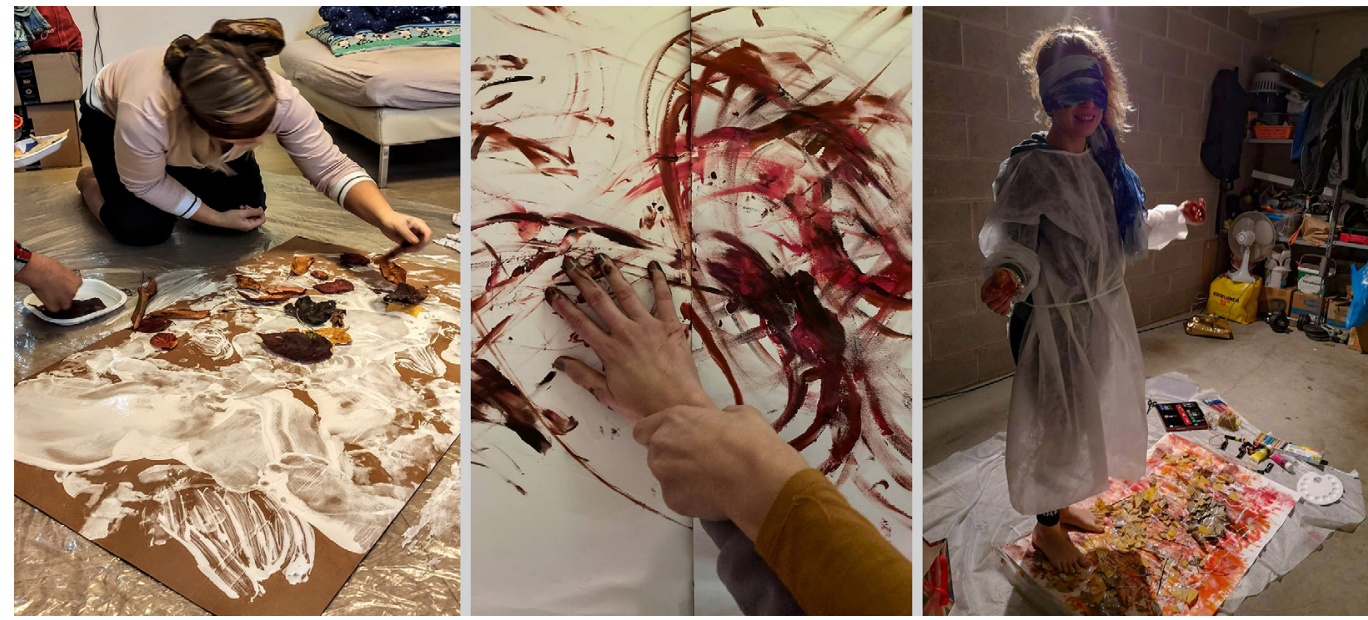

impositiva nell'organizzazione per permettergli di appropriarsi del ruolo di guida discreta, quasi invisibile, per lasciare spazio agli allievi. La conduzione della lezione è stata infatti autogestita in modo autonomo dagli alunni [Antognazza, Romualdi 2020], ma attuata nello spazio di apprendimento creato dal docente; l'istruzione è divenuta costruzione libera e indipendente per gli scolari.

Le lezioni sono state precedute da brevi note inviate, con due-tre giorni di anticipo, via email ai partecipanti; questo al fine di dare la possibilità agli studenti di recuperare i materiali necessari all'esercitazione, nonché di destare la loro attenzione sulle future attività. Brevi descrizioni sintetiche con scopi e obbiettivi indicati in modo chiaro, ma senza alcuna informazione e/o indirizzo di esecuzione, al fine di permettere a ogni gruppo di giungere al loro risultato in modo libero, senza rigidità e forzate intromissioni (fig. 2); pochi ragguagli e ridotte regole non troppo vincolanti [Perissinotto, Bruschi 2020] al fine di far seguire agli allievi la propria strada, facendoli collaborare tra loro.

II lavoro in team è stata una priorità del corso, molti laboratori sono stati appunto imperniati sullo scambio e sulla complicità dei membri. Si è quindi chiesto di creare gruppi di lavoro nel rispetto delle regole per la sicurezza e al fine di evitare il contagio. I ragazzi hanno quindi evitato gli spostamenti e hanno coinvolto gli amici stretti, i familiari, i compagni del paese (fig. 3): raggruppamenti ristretti con cui condividono la quotidianità al fine di limitare la mobilità e non frequentare persone estranee al proprio quotidiano. Forzati a lavorare in gruppo ma lasciati liberi di scegliere se agire in presenza tra loro (nel pieno rispetto delle indicazioni contro il contagio e nell'isolamento del gruppo limitato al paese e/o all'ambito familiare) o attraverso l'interfaccia virtuale dei loro PC.
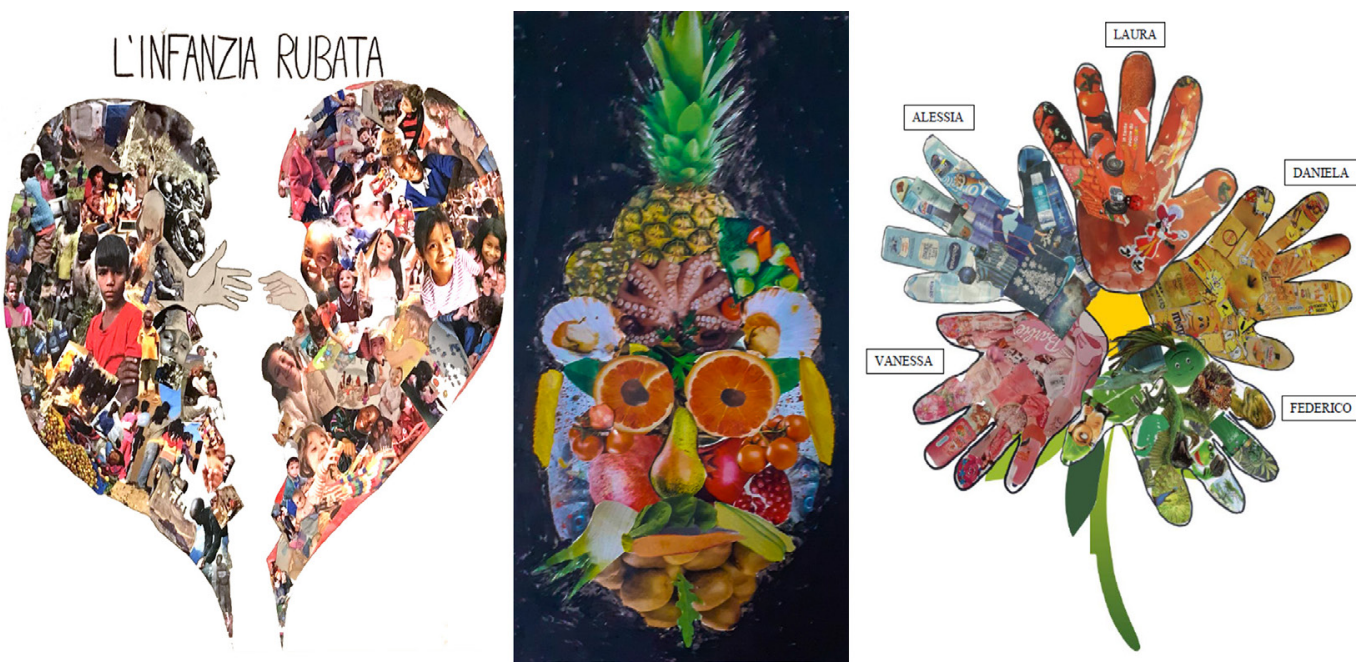
Fig. 8. L' atelier II Fumetto: il disegno e il visual story telling per narrare, attraverso le immagini, una propria storia.
L'esperienza ha visto anche il coinvolgimento inaspettato delle scuole; i maestri che svolgevano attività di supplenza negli istituti hanno infatti accolto l'occasione di seguire le lezioni in remoto con i bimbi della classe, attivando i laboratori. Un'attività sperimentale di grandissimo interesse e notevole importanza formativa, un tirocinio pratico e una diretta applicazione dei concetti acquisiti durante il corso (fig. 4).

Le lezioni, come in presenza, seguivano una precisa tempistica scandita da una fase introduttiva, una fase di preparazione ed esecuzione seguita dalla condivisione dei risultati e la loro autovalutazione, e infine la fase conclusiva. La piattaforma era l'agorà virtuale dove i ragazzi si rapportavano; tutti erano chiamati a lasciare accese le loro camera durante l'esecuzione dei lavori in modo da ricreare un'unica classe virtuale diffusa nel territorio. Un reality movie in presa diretta che, istante per istante, documentava e raccontava lo straordinario mondo gioioso degli atelier, attraverso il divertimento dei ragazzi, la loro fantasia, la loro voglia di 'mettersi in gioco' e di condividere esperienze ed emozioni.

Le riprese e i lavori sono stati alla base della preparazione dell'esame (in particolare sono stati realizzati quattro laboratori: animare l'inanimato, disegnare bendati con mani e piedi, il photo-collage e il fumetto), esposti durante la verifica con un portfolio (figg. 5-7) e un cortometraggio (fig. 8).
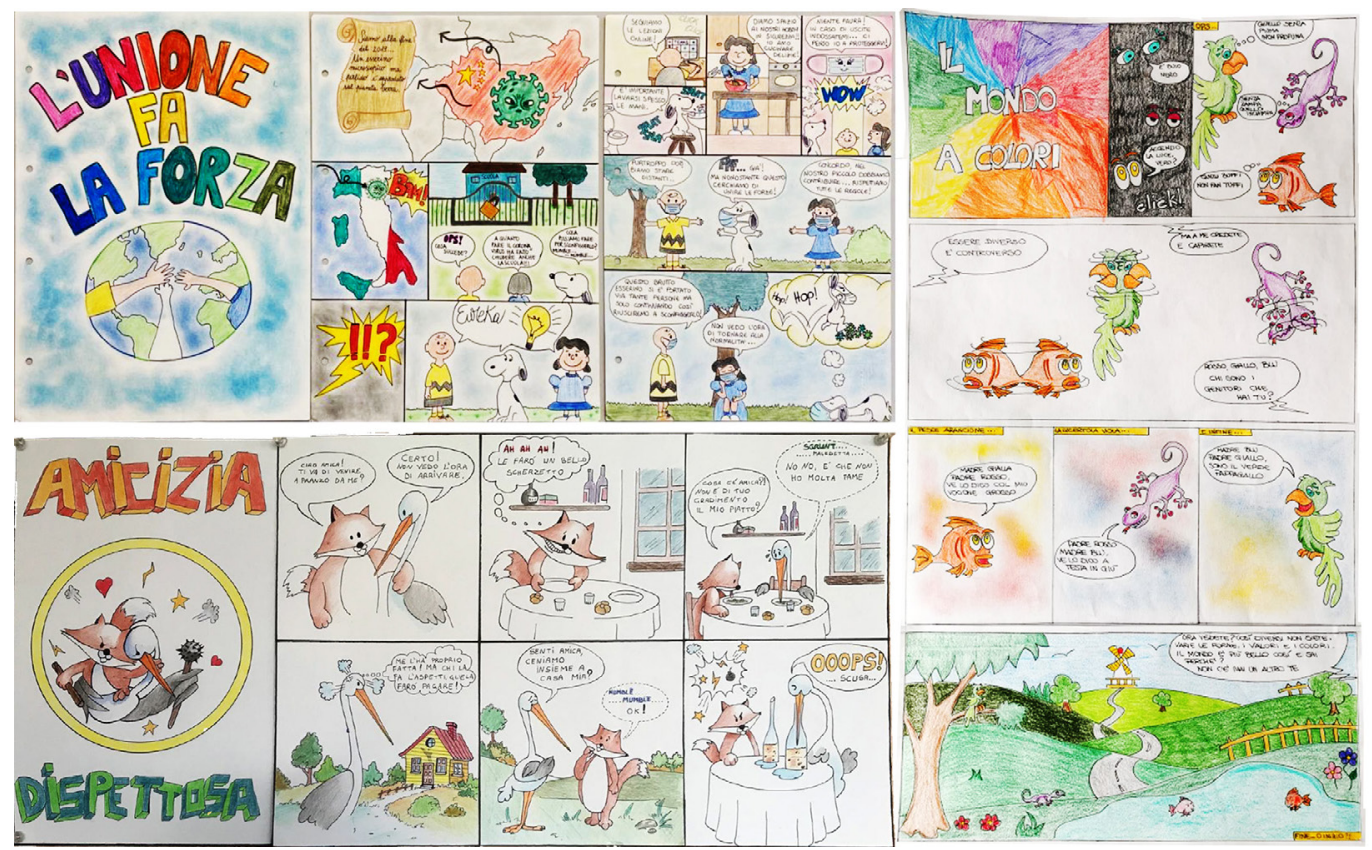

\section{Conclusioni}

I disagi della didattica digitale 'in remoto' a cui siamo stati costretti dalla pandemia è stata una sfida che ci ha spinto a ricercare nuove forme di insegnamento possibili grazie all'impiego delle piattaforme e-learning. Un cambiamento che avrà certamente una forte ricaduta, anche quando la situazione emergenziale sarà cessata, perché ha permesso un'evoluzione dell'insegnamento. II blended learning consente di poter venire incontro a particolari esigenze dei ragazzi sino a oggi trascurate; la possibilità di poter partecipare alla lezione da luoghi molto distanti dall'ateneo e di poterne fruire più volte e in momenti diversi, permettono di poter coinvolgere una platea più ampia di studenti. Questione di fondamentale importanza allinterno del percorso in laurea in Scienza delle Formazione Primaria in cui un alto numero di studenti, i c.d. 'lavoratori', sono già inseriti nel mondo della scuola e spesso impossibilitati alla frequenza dei corsi.

Un aspetto innovativo che consente di stabilire anche una relazione diretta con le attività di tirocinio nelle scuole; la possibilità di partecipare a distanza a un laboratorio, in caso coinvolgendo la stessa classe di alunni, permette l'applicazione diretta dell'insegnamento e il riscontro immediato dell'efficacia attraverso la risposta dei bimbi [I]. 
Fig. 9. La pagina Facebook del C.l. di Disegno, Arte e Musica: archivio open access per la conservazione e la condivisione dei cortometraggi realizzati dagli studenti per comunicare al mondo la loro esperienza al tempo della pandemia.

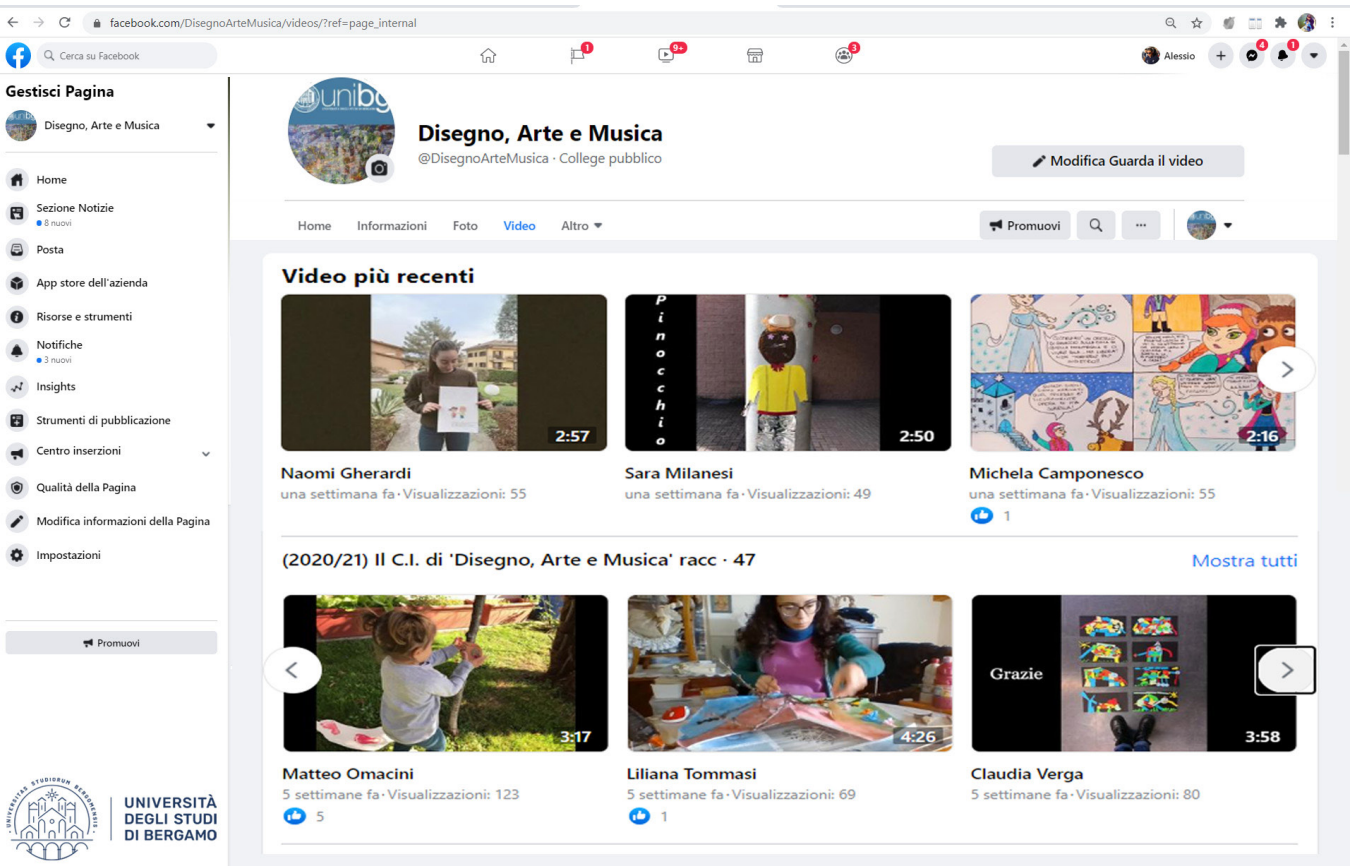

Note

[I] L'entusiasmo e la gioia di vivere degli studenti sono stati alla base del successo del corso; a loro va il mio più sentito ringraziamento perché hanno dato senso al mio ruolo di docente. Le immagini allegate al saggio che li ritrae sorridenti e motivati, più di molte parole ritengo che possano esprimere come la costrizione di una didattica a distanza si sia invece tradotta in una opportunità di integrazione da cui trarre ispirazione per le attività future.

\section{Riferimenti bibliografici}

AA.W. (2019). Piccoli equivoci sulle competenze: intervista alla prof.ssa Anna Maria Ajello, presidente dell'Invalsi. In Sguardi sulla Scuola. Roma: InvalsiOpen: <https://www.invalsiopen.it/piccoli-equivoci-sulle-competenze/> (consultato il 20 marzo 202 I).

Antognazza D., Romualdi M. (2020). Dad e oltre: consigli e pratiche per insegnare ed educare nella didattica a distanza e integrata. Torrazza Piemonte: Independently Published.

Bruschi M. (2020). Nota con le indicazioni operative per la didattica a distanza. In Comunicati del Ministero dell'Istruzione dell'Università e della Ricerca. Roma: Miur, Nota prot. 388 del 17.03.2020. <https://www.miur.gov.it/web/guest/-/coronavirus-emanata-la-nota-con-le-indicazioni-operative-per-la-didattica-a-distanza> (consultato il 20 marzo 202I).

Cardaci A. (2020). II disegno per l'infanzia: approcci interdisciplinari per una nuova forma di didattica. In A. Arena et al. (a cura di). Connettere: un disegno per annodare e tessere. Atti del $42^{\circ}$ Convegno UID, pp. 2 16-237. Milano: FrancoAngeli.

Castoldi M. (2020). Gli ambienti di apprendimento: ripensare il modello organizzativo della scuola. Palermo: Editore Carocci.

Elleran P. (2020). Costruire l'ambiente di apprendimento: prospettive di cooperative learning, service learning e problem-based learning. Teramo: Liscianilibri Editore.

Milito D., Tataranni A. (2019). Didattica innovativa nell'era digitale. Roma: Editore Anicia.

Mulè P. (20I2). II problema teorico dell'educazione ed il ruolo dell'educatore nell'Emilio. Alcune riflessioni pedagogiche. In Formazione, Lavoro, Persona, n. 6, pp. I-12.

Nardi E. (2020). Jean-Jacques Rousseau, un geniale precursore dell'istruzione a distanza. In CADMO (2), pp. 19 -36.

Perissinotto A., Bruschi B. (2020). Didattica a distanza: com’è, come potrebbe essere. Roma: Giuseppe Laterza \& Figli.

Rousseau J. J. ( 1762-1965). Émile ou dell'Éducation - Emilio, traduzione integrale, introduzione e note a cura di Giuseppe Roggerone. Brescia: Editrice La Scuola.

Autore

Alessio Cardaci, Università di Bergamo, alessio.cardaci@unibg.it

Per citare questo capitolo: Cardaci Alessio (2021). II disegno per l'infanzia al tempo della pandemia: l'esperienza del c.i. di disegno, arte e musica di unibg/Drawing for children in a pandemic era: the experience of the c.i. of drawing, art and music of unibg. In Arena A, Arena M. Mediati D. Raffa P. (a cura di). Connettere. Un disegno per annodare e tessere. Linguaggi Distanze Tecnologie. Atti del $42^{\circ}$ Convegno Internazionale dei Docenti delle Discipline della Rappresentazione/Connecting Drawing for weaving relationship. Languages Distances Technologies. Proceedings of the $42^{\text {th }}$ Internationd Conference of Representation Disciplines Teachers. Milano: FrancoAngeli, pp. 1435 - 1450 


\title{
Drawing for Children in a Pandemic Era: the Experience of the C.I. of Drawing, Art and Music of UniBg
}

\author{
Alessio Cardaci
}

\section{Abstract}

The teaching of Drawing within the degree courses in Primary Education calls for new reflections in our sector in order to reshape teaching, no longer aimed at training engineers and architects, but educators. Professional figures who will have to use the graphic tool, not for the understanding and enhancement of architecture and landscape, but as a fundamental means for communicating the child's interior space. An extended conception of the discipline, devoid of a direct link with the representation of the architectural and natural heritage, hinged on a close relationship with the visual arts and the doctrines of art history and social sciences. The pandemic crisis has called us to new challenges by forcing us to the intensive use of 'remote' digital teaching; the essay presents reflections born from the experience gained within the course of Drawing, Art and Music active at the University of Bergamo, highlighting how blended learning can offer, if used in an appropriate way, new opportunities to overcome the limits of traditional education in presence only.

\section{Keywords}

cooperative learning, art and music, primary school, pedagogy, psychology, Bergamo.

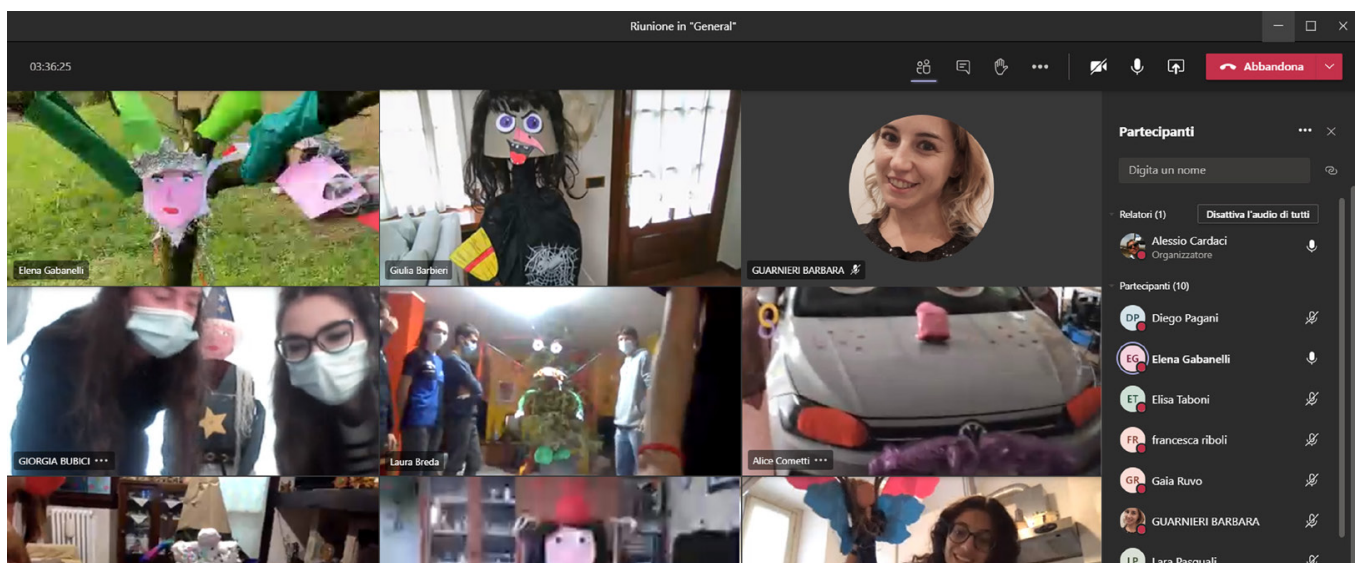




\section{Introduction}

The Coronavirus pandemic crisis (Covid 19) has accelerated a series of processes that were already underway in our society; the university world has been forced to make major changes in the teaching sector, but, above all, it has had to implement profound changes in the way its teachings are delivered. Universities were forced to embark on the path of digital interaction, combining face-to-face with distance learning. A revolution triggered by sudden and unexpected causes that forced a transformation, which materialized in a very short time and, perhaps, possible only because it was founded on mature reflections that have animated the pedagogical debate of the past years. An upheaval still in place that, to date, we do not know when it will end; an upheaval that will make it impossible to return to a status quo prius and, probably, will lead us to a new form of education.

Blended learning, a term in vogue today to indicate a form of hybrid learning (even remotely) through digital tools, has allowed during the lockdown (and still allows it during forced closures, when necessary to counteract the increase in contagions), not to interrupt the learning path and the dialectical relationship between teacher and learner, as well as to "keep the class and school community alive, the sense of belonging and fight the risk of isolation and demotivation" [Bruschi 2020, p. 2].

The great challenge today is the construction of new learning environments, in the full awareness that teaching "must provide for the reasoned and guided construction of knowledge through an interaction between teachers and pupils: whatever the means through which teaching is practiced, the purpose and the principles do not change" [rif. cit.. ..., p. 3]. It is therefore necessary to create new spaces, intended not only as physical places, but cognitive environments aimed at stimulating the student with significant experiences on an emotional and affective, social and interpersonal level, knowledge and culture [Castoldi 2020].

The essay, through the experience of the $\mathrm{Cl}$ of Drawing, Art and Music active at the University of Bergamo held during the pandemic, proposes methodological reflections related to the teaching of the disciplines of representation in the courses of Science of Primary Education, in order to take advantage of the experience that such a negative event has produced anyway.
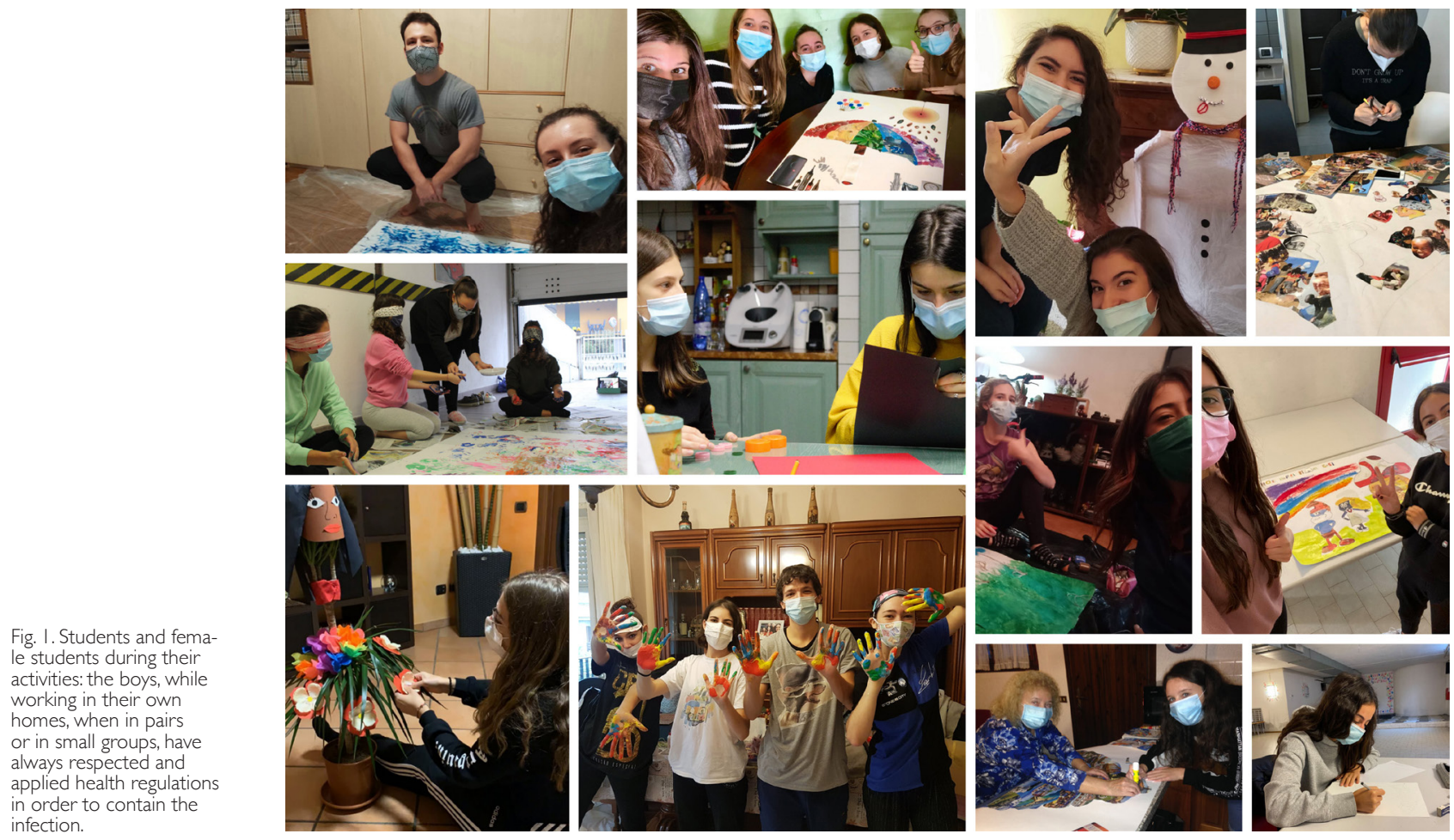


\section{Distance learning environments and digital training}

Knowledge (understood as the two-way and inseparable relationship between knowledge and competence), and the way in which it is constructed in the student, is influenced by a multitude of factors that intercede in the educational process: teachers and students, the cultural context and social, technical and methodological tools. Being competent, in fact, means mastering knowledge and being able to exploit one's scientific-cultural background to adapt to different circumstances; it is necessary that the transmission of contents takes place within a relationship of close complicity between teacher and learner to allow the stimulation of competence, giving the student a transversal and interdisciplinary awareness to be used in heterogeneous and unexplored fields [Aiello 2019].

The learning environment serves as the basis for this process. It is a set of structured activities for the construction and passage of knowledge, as well as to stimulate interaction between pupils on the basis of common interests and purposes [Elleran 2020]. The topic, much debated in the field of Educational Sciences, marks a watershed in traditional teaching through a new concept of education based not on 'what to teach' but 'on how to teach'; a new vision that focuses training on the needs of the learner and on the processes in which this occurs.

In this context, digital teaching, even 'remotely', is a new and powerful tool at the teacher's service, although not without its critical issues; it must be considered an integrative tool to the traditional method in presence but can never be a substitute. In fact, the individual use of the lessons from one's home, while allowing the transmission of science and culture, raises legitimate concerns about the risks associated with the social dimension and interpersonal relationships of the users (a statement that, in the age of social networks, is quite unique). A purely autonomous study outside the university classrooms, although apparently it does not seem to affect the relationship between the teacher and the student (indeed it strengthens it for the direct and immediate use of digital communication), certainly alters the perception of the academy.

According to many authors, digital distance learning has its foundation in the educational concept theorized by Jean-Jacques Rousseau and expressed in the work Émile ou dell'Éducation, published in France in the second half of the I8th century. A thought that has been re-evaluated in light of the current condition because, especially in the considerations of the role of the educator, it is well suited to teaching 'remotely' [Nardi 2020]. According to

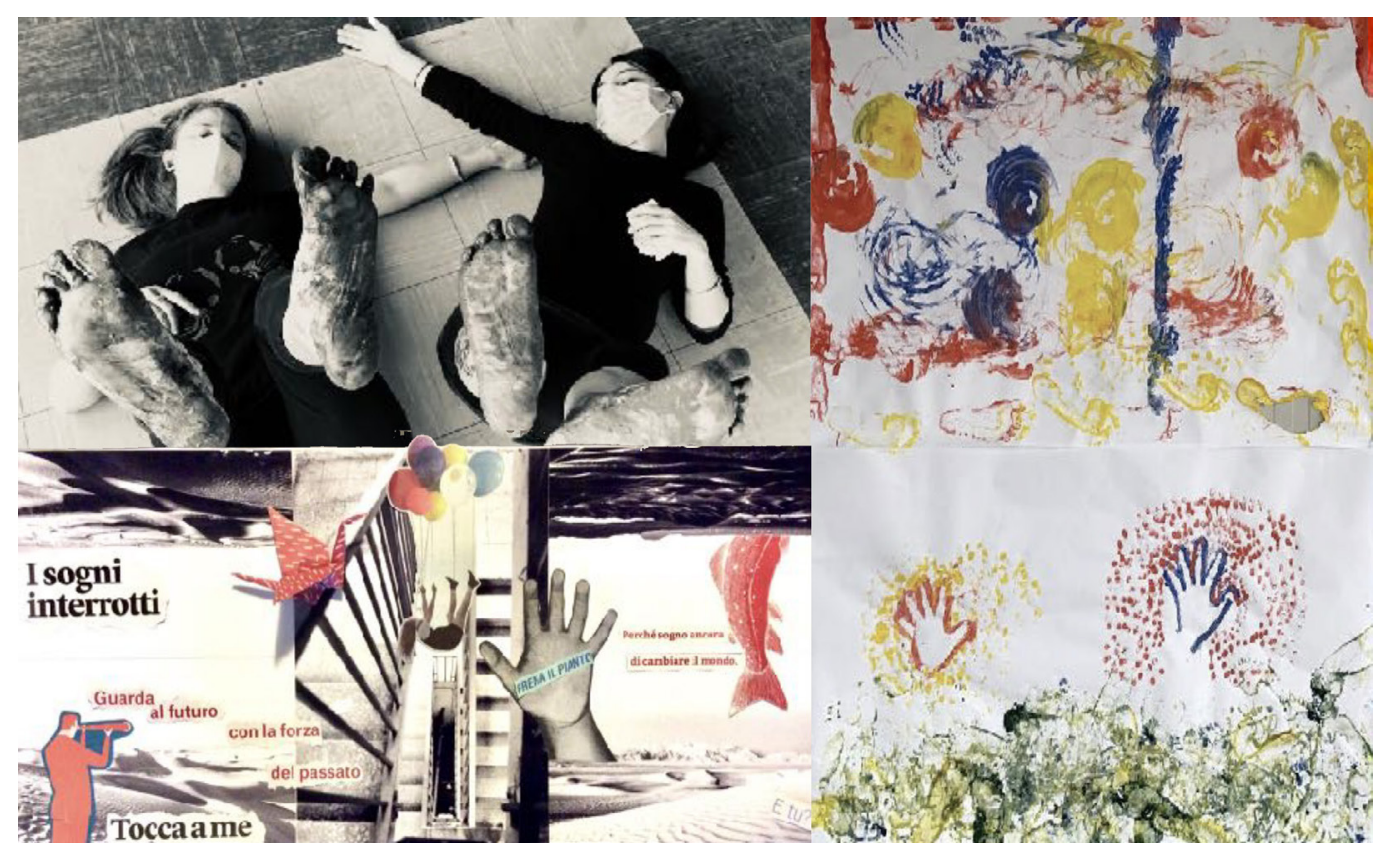


Fig. 3. The groups that were formed within the families: the students, in order to carry out their work, involved their families (fathers, grandparents and 'mothers' and their children)
Fig. 4. The workshops followed in the schools by the students engaged in substitute activities who forther gether with the primary school children, Involving the
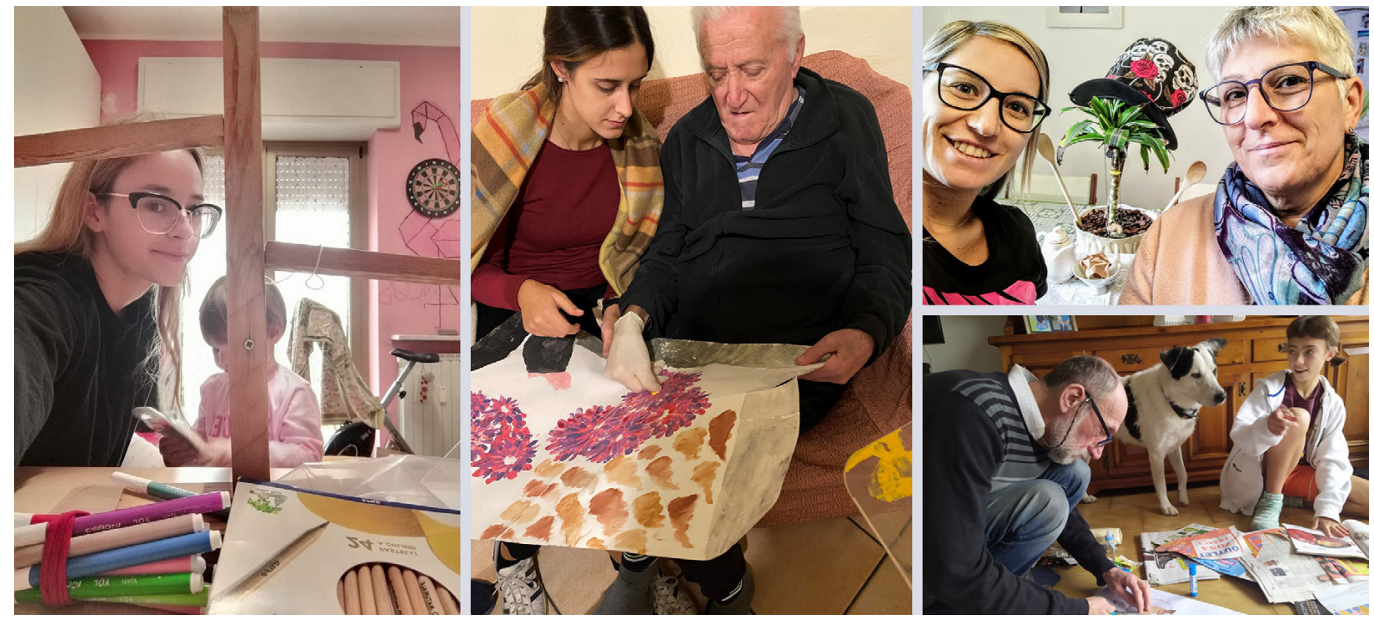

Rousseau, a student's education must take two successive forms: negative education and indirect education.

The negative teaching is implemented without any intervention of the teacher whose role is to follow the training of the pupil without imposing anything, because the "only teacher" has to be experienced. The tutor must create a learning place that allows students to experiment while preserving the spontaneous and original dimension of the student's spirit; therefore "not in teaching virtue and truth, but in preserving the heart from vice and the spirit from error" [Rousseau 1762-1965, p. 90].

Indirect education is based on the awareness that learning is not a purely intellectual fact, but the result of concrete exercise combined with personal reflection; the teacher must guide his pupil without giving precepts. Understanding must come from experimentation, from the realization of things related to interest and aroused by curiosity. The educator should not search for the best teaching methods but should awaken the desire to learn. Immediate participation is therefore the basis of learning; to be efficient and present, cur-
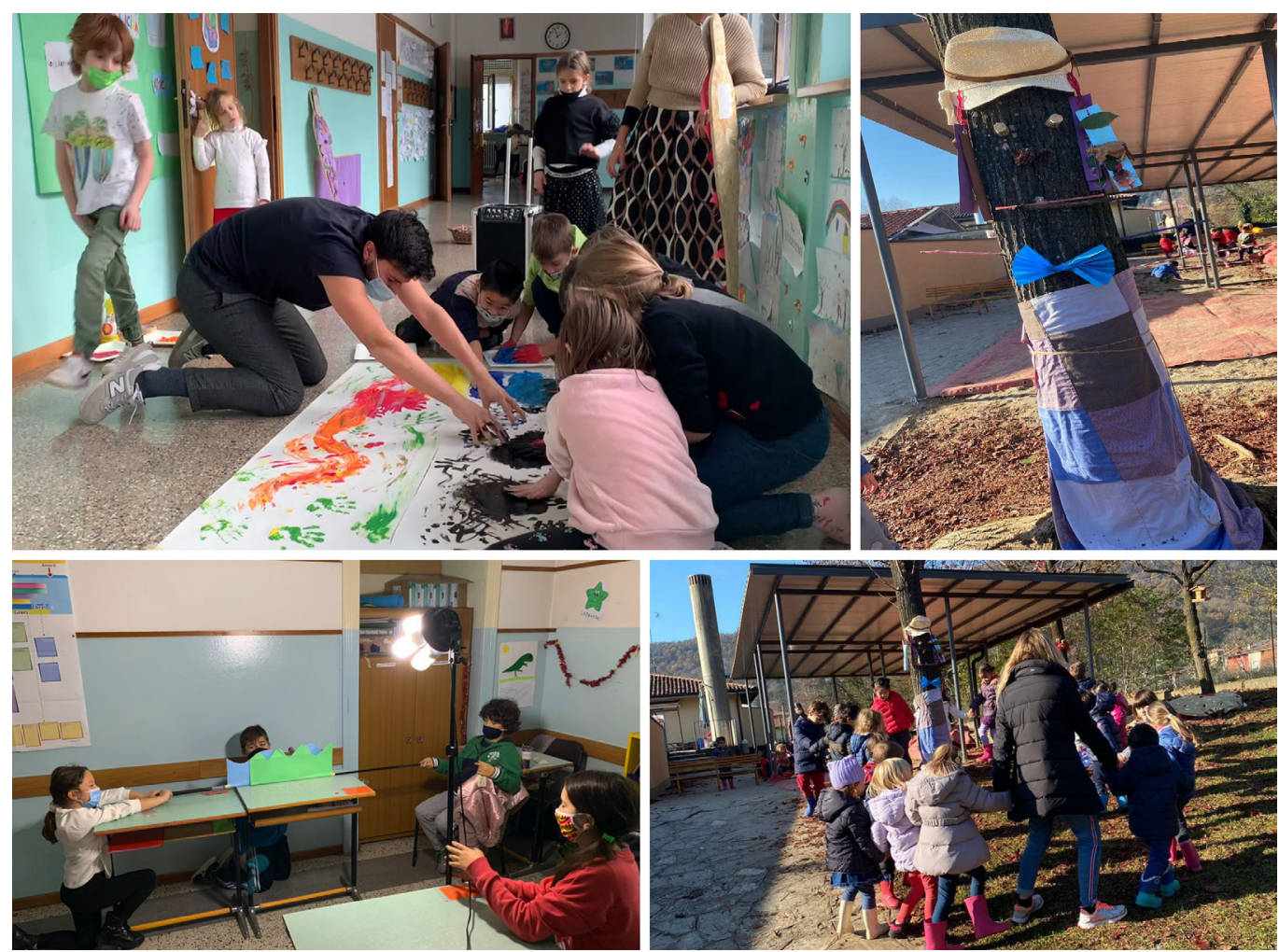
Fig. 5.The workshop Animate the inanimate: plants, radiators, stoves and chairs are transformed into figures reminding characters of fairy tales rent and concrete, as well as to have utility as a basis. The teacher must give the pupil the impression that he "does everything without doing anything", making the pupil have the perception that his experiences are random, while on the contrary they are planned by the educator [Mulè 2019].
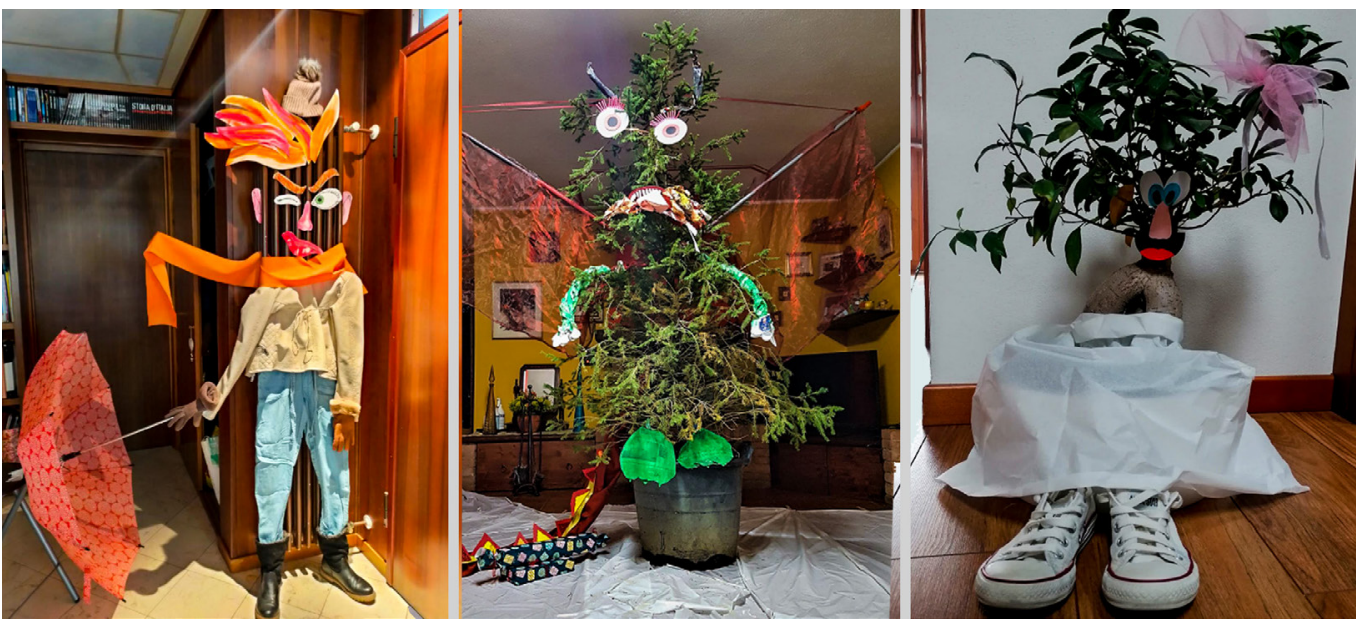

The C.I of Drawing, Art and Music active at the University of Bergamo is a teaching born from the integration of skills between the fields of pedagogy, psychology and the science of representation. Its primary objective is to bring students closer to perception and visual communication, to educate them in reading images, to stimulate them to use the graphic technique as an expressive means of emotional communication; a vision of the Drawing that intends to attribute to the noun the meaning "OF itself the SIGN", relating the activities to the individual who uses shapes and colors to express their inner world. Learning is therefore based on the interest and pleasure of the students to get to know each other and to enrich and enrich their souls. It is therefore not important to tell a student how to draw, but to make him fall in love with drawing within a self-learning path that will stimulate him to grow and improve [Cardaci 2020].

The pandemic and the inability to operate normally in universities has forced a different form of child participation. The primary objective, also through digital, was to revive the 'spirit of the course' as if it were carried out in person, not an easy step for teaching based on laboratory activity as a binding element of the various disciplines, including psychomotor action.

For this purpose, the platforms for distance learning have been used not as a simple communication tool, but as a computer device capable of extending the classroom beyond the physical boundaries of the university, in a widespread and widespread way in the territory (cover). Smartphones and tablets have turned into cameras to connect distant places and realities, as well as share experiences and events, joys and passions; means of union exploited transversely to their original functions to allow students to carry out the ateliers 'safely', without having the impression of being isolated or distant from each other (fig. I). An electronic eye capable of observing and transmitting the initiatives carried out by individual groups and, at the same time, a viewing screen in the world to always be in close and direct contact with each other.

To this end, it was important to reduce the centralizing function of the teacher, often all-encompassing in 'remote' teaching where the teacher invades the monitor and manages speaking times with microphone control [Milito, Tataranni 2019]. The course of the lesson in fact provided for the 'vision' of the teacher only in the initial and final phase, keeping the room off (or in floating mode, reduced to a small icon at the top) for the rest of the time. The 'visual' presenters of the professor and his taxing function in the organization were therefore weak- 
Fig. 6. The workshop Drawing blindfolded, with hands and feet: abstract drawing made without the sense of sight, seeing the color with a touch and using hands and feet as brushes to create one's
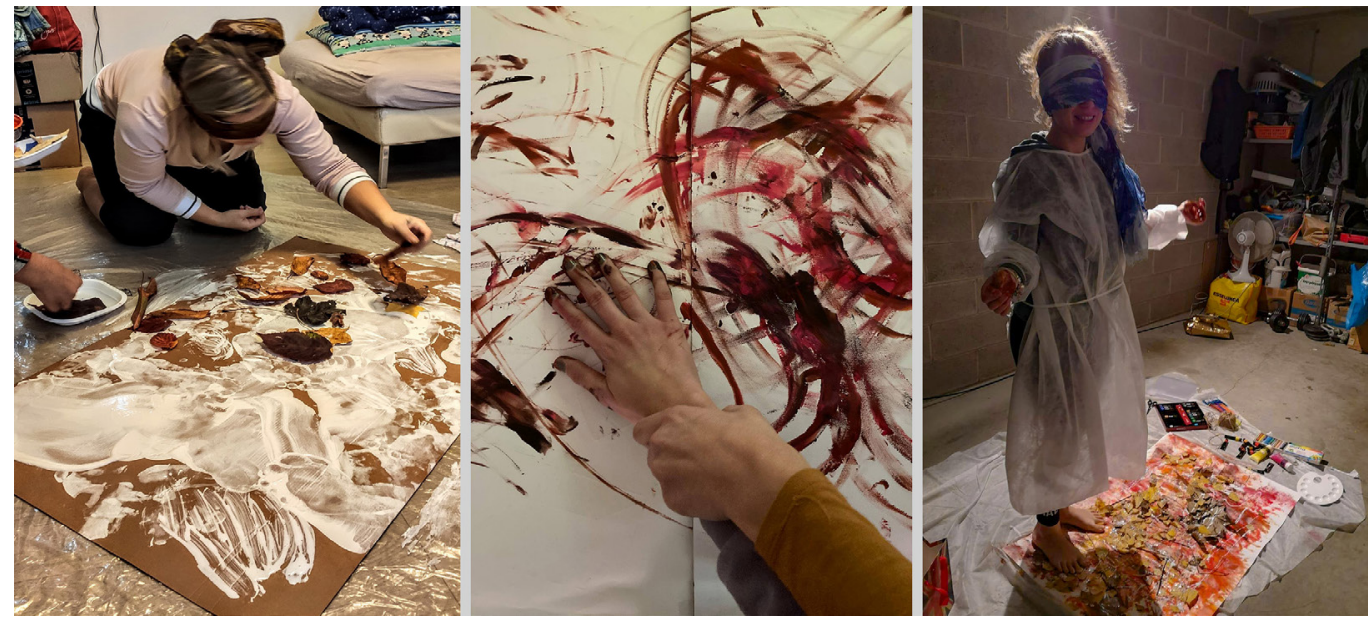

ened to allow him to appropriate the role of discreet, almost invisible guide, to make room for the students. The conduct of the lesson was in fact self-managed, independently by the students [Antognazza, Romualdi 2020], but implemented in the learning space created by the teacher; education has become a free and independent construction for schoolchildren. The lessons were preceded by short notes sent, two or three days in advance, via email to the participants; this in order to give students the opportunity to retrieve the materials necessary for the exercise, as well as to draw their attention to future activities. Short synthetic descriptions with aims and objectives clearly indicated, but without any information and / or direction of execution, in order to allow each group to arrive at their result in a free way, without rigidity and forced interference (fig. 2); little information and limited rules that are not overly restrictive [Perissinotto, Bruschi 2020] in order to follow students on their own path, forcing them to collaborate with each other.

Teamwork was a priority of the course, many workshops dealt with the exchange and complicity of members. It was therefore asked to set up working groups in accordance with safety rules and to avoid contagion. Young people thus avoid travelling and involve close friends, family members, comrades from the village (fig. 3): small groups with which they share their daily life so as to limit mobility and not associate with people who do not know their daily life. Forced to work in groups but left free to choose whether to act in the presence of each other (in full compliance with the indications against contagion and in the isolation of the group limited to the country and / or family environment) or through the virtual interface of their PC.
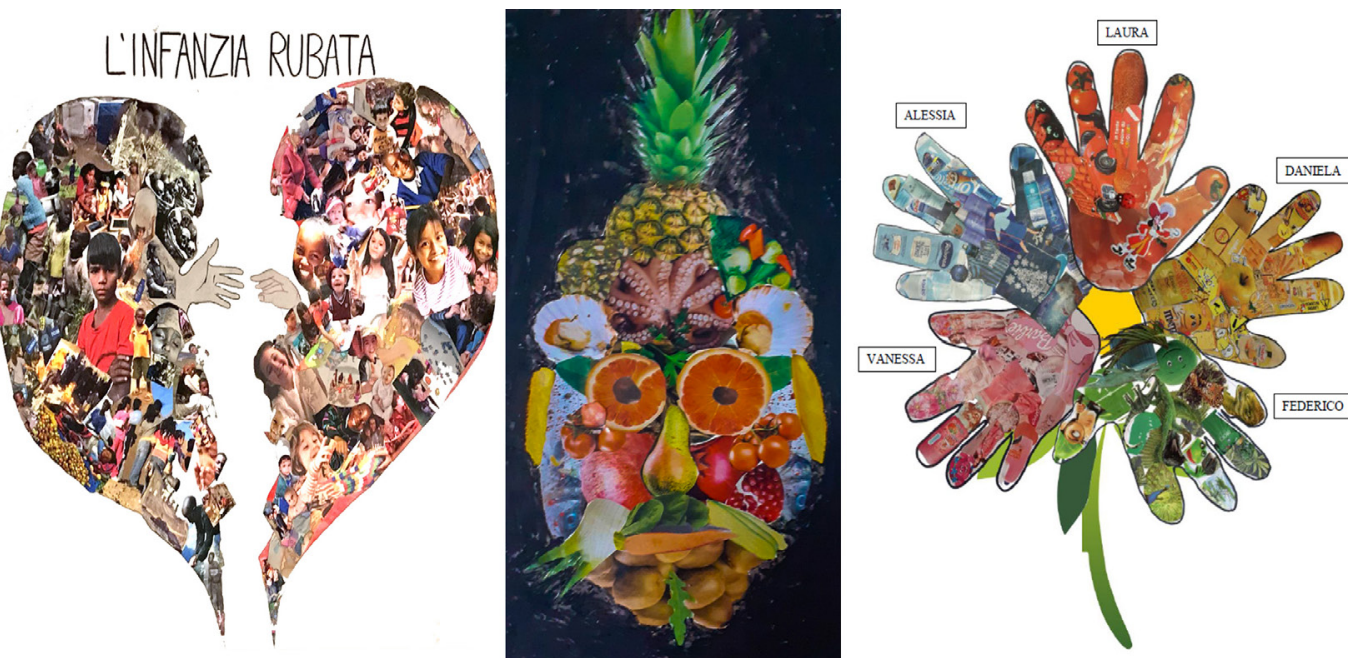
The experience also saw the unexpected involvement of schools; the teachers who carried out temporary work in the institutes in fact welcomed the opportunity to follow the lessons remotely with the children in the class, activating the workshops. An experimental activity of great interest and considerable educational importance, practical training and direct application of the concepts acquired during the course (fig. 4).

The lessons, as in the presence, followed a precise timing marked by an introductory phase, a phase of preparation and execution followed by the sharing of the results and their self-assessment, and finally the concluding phase. The platform was the virtual agorà where the boys interacted; all were asked to leave their rooms switched on during the execution of the works in order to recreate a single virtual classroom widespread in the area. A live reality movie that, moment by moment, documented and told the extraordinary joyful world of the ateliers, through the fun of the kids, their imagination, their desire to 'get involved' and share experiences and emotions.

The shots and the works were the basis of the preparation for the exam (in particular, four workshops were carried out: animating the inanimate, drawing blindfolded with hands and feet, the photo-collage and the comic), exhibited during the verification with a portfolio (figs. 5-8) and a short movie (fig. 9).

Fig. 8. The Comics workshop: drawing and visual narration to tell your own story through images.
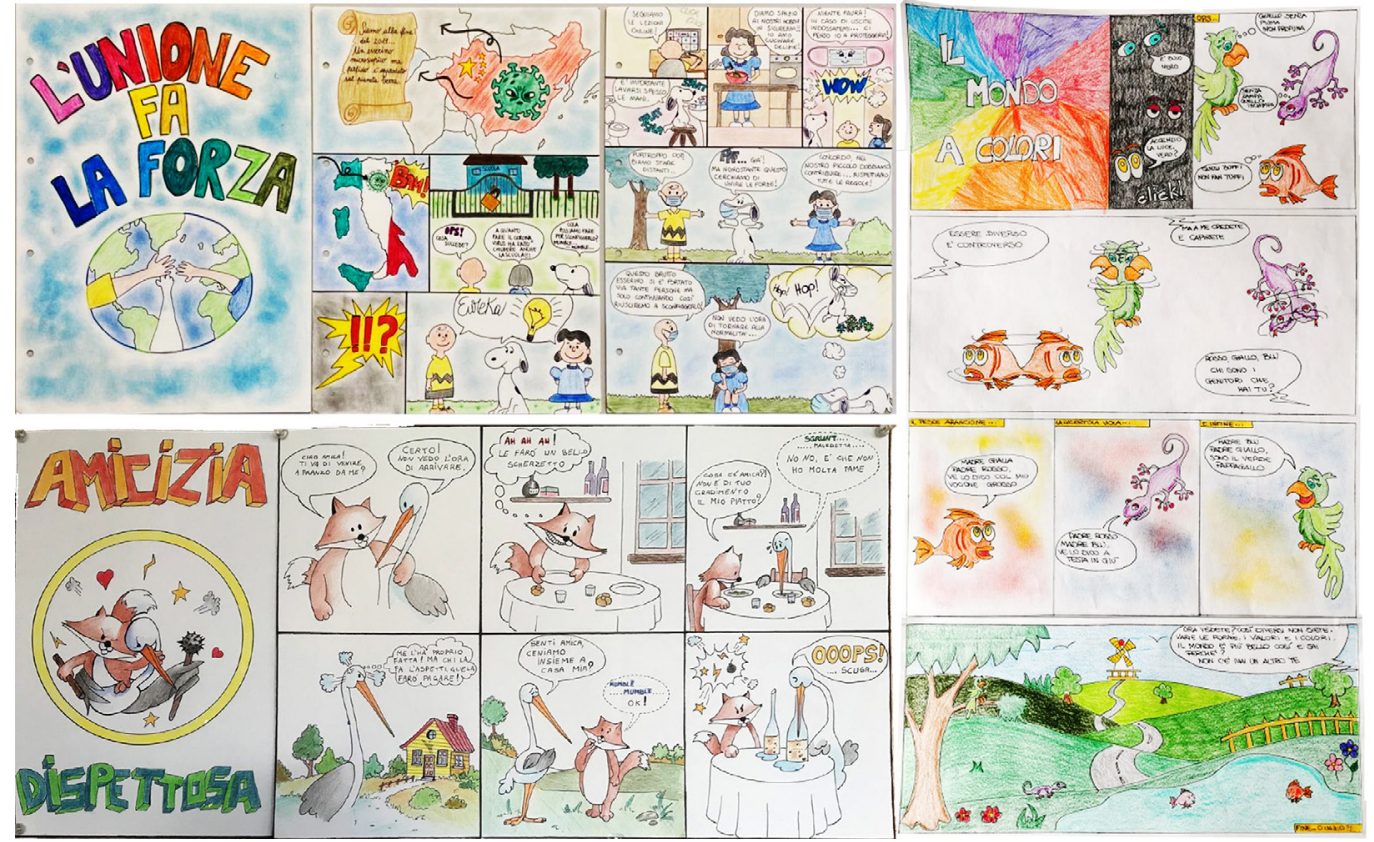

\section{Conclusions}

The inconvenience of 'remote' digital teaching that we have been forced to by the pandemic was a challenge that prompted us to seek new forms of teaching possible thanks to the use of e-learning platforms. A change that will certainly have a strong impact, even after the emergency has ended, as it has enabled an evolution in education. Blended learning makes it possible to meet the particular needs of children, which have been neglected until now; the possibility of being able to participate in the lesson from places far away from the university and being able to use it several times and at different times, allows you to involve a wider audience of students. An issue of fundamental importance within the degree course in Primary Education in which a high number of students, the so-called 'workers', are already included in the school world and are often unable to attend courses.

An innovative aspect that also allows you to establish a direct relationship with internship activities in schools; the possibility of participating remotely in a laboratory, in cases involving the same class of pupils, allows the direct application of the teaching and the immediate confirmation of the effectiveness through the response of the children [I]. 
Fig. 9. The Facebook page of the C.I. of Drawing, Art and Music: open access archive for the conservation and sharing of short films made by students to communicate their experience to the world at the time of the pandemic.

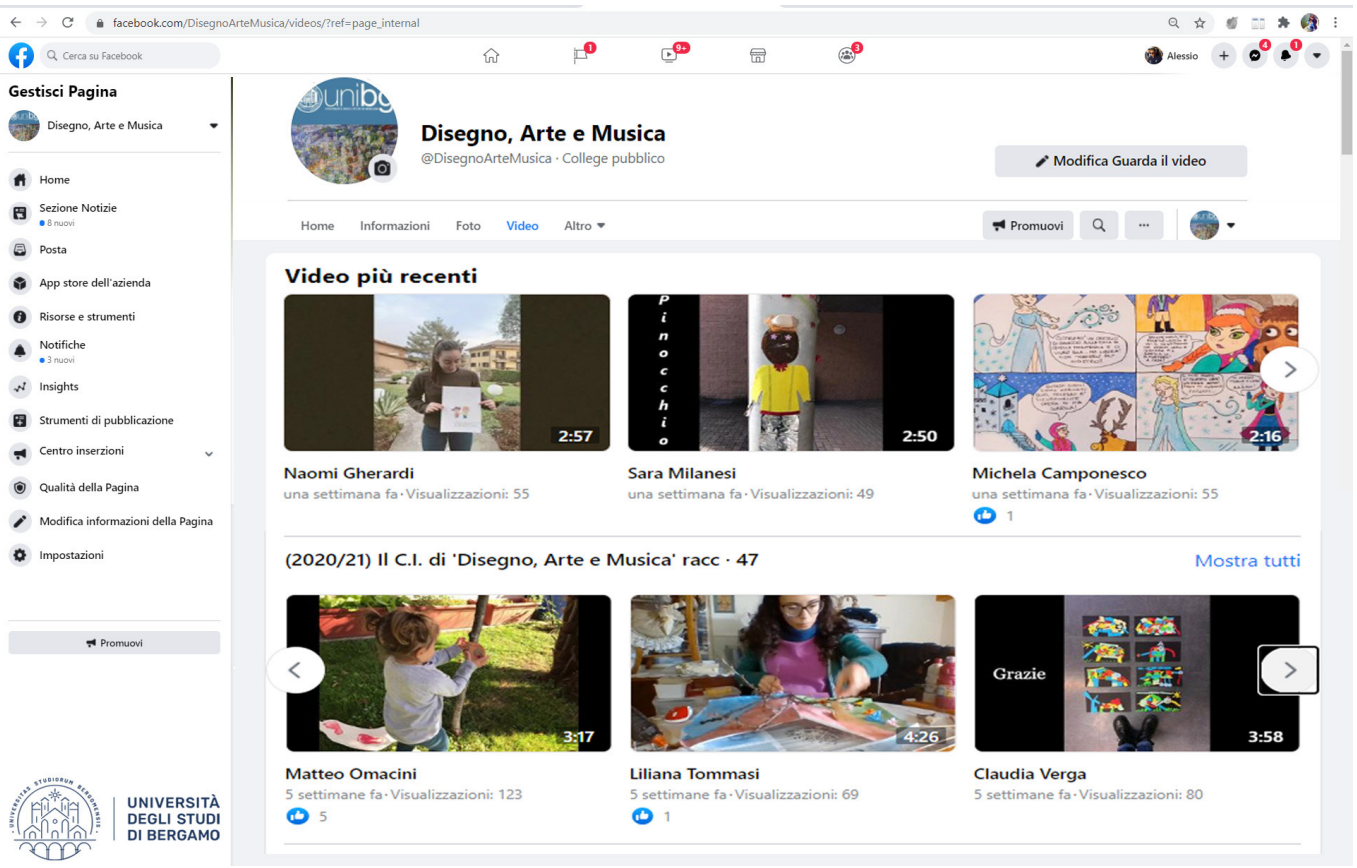

Notes

[I]The students' enthusiasm and joie de vivre were the basis for the success of the course; my heartfelt thanks go to them because they gave meaning to my role as a teacherThe images attached to the essay that portrays them smiling and motivated I think more than many words can express how the constraint of distance learning has instead translated into an opportunity for integration from which to draw inspiration for future activities.

\section{References}

AA.W. (2019). Piccoli equivoci sulle competenze: intervista alla prof.ssa Anna Maria Ajello, presidente dell'Invalsi. In Sguardi sulla Scuola. Roma: InvalsiOpen: <https://www.invalsiopen.it/piccoli-equivoci-sulle-competenze/> (consultato il 20 marzo 202 I).

Antognazza D., Romualdi M. (2020). Dad e oltre: consigli e pratiche per insegnare ed educare nella didattica a distanza e integrata. Torrazza Piemonte: Independently Published.

Bruschi M. (2020). Nota con le indicazioni operative per la didattica a distanza. In Comunicati del Ministero dell'Istruzione dell'Università e della Ricerca. Roma: Miur, Nota prot. 388 del 17.03.2020. <https://www.miur.gov.it/web/guest/-/coronavirus-emanata-la-nota-con-le-indicazioni-operative-per-la-didattica-a-distanza> (consultato il 20 marzo 202I).

Cardaci A. (2020). II disegno per l'infanzia: approcci interdisciplinari per una nuova forma di didattica. In A. Arena et al. (a cura di). Connettere: un disegno per annodare e tessere. Atti del $42^{\circ}$ Convegno UID, pp. 2 16-237. Milano: FrancoAngeli.

Castoldi M. (2020). Gli ambienti di apprendimento: ripensare il modello organizzativo della scuola. Palermo: Editore Carocci.

Elleran P. (2020). Costruire l'ambiente di apprendimento: prospettive di cooperative learning, service learning e problem-based learning. Teramo: Liscianilibri Editore.

Milito D., Tataranni A. (2019). Didattica innovativa nell'era digitale. Roma: Editore Anicia.

Mulè P. (2012). II problema teorico dell'educazione ed il ruolo dell'educatore nell'Emilio. Alcune riflessioni pedagogiche. In Formazione, Lavoro, Persona, n. 6, pp. I-12.

Nardi E. (2020). Jean-Jacques Rousseau, un geniale precursore dell'istruzione a distanza. In CADMO (2), pp. 19 -36.

Perissinotto A., Bruschi B. (2020). Didattica a distanza: com’è, come potrebbe essere. Roma: Giuseppe Laterza \& Figli.

Rousseau J. J. ( 1762-1965). Émile ou dell'Éducation - Emilio, traduzione integrale, introduzione e note a cura di Giuseppe Roggerone. Brescia: Editrice La Scuola.

Author

Alessio Cardaci, Università di Bergamo, alessio.cardaci@unibg.it

To cite this chapter. Cardaci Alessio (202 I ). Il disegno per l'infanzia al tempo della pandemia: l'esperienza del c.i. di disegno, arte e musica di unibg Drawing for children in a pandemic era: the experience of the c.i. of drawing art and music of unibg. In Arena A., Arena M., Mediati D. Raffa P. (a cura di). Connettere. Un disegno per annodare e tessere. Linguaggi Distanze Tecnologie. Atti del $42^{\circ}$ Convegno Internazionale dei Docenti delle Discipline della Rappresentazione/Connecting. Drawing for weaving relationship. Languages. Distances Technologies. Proceedings of the $42^{\text {th }}$ Internationa Conference of Representation Disciplines Teachers. Milano: FrancoAngeli, pp. | 435- | 450. 